\title{
СТАТИСТИЧНЕ ДОСЛІДЖЕННЯ ІННОВАЦІЙНОГО ФОНУ УКРАЇНСЬКИХ ПІДПРИЄМСТВ НА ТЛІ РЕЦЕСІї
}

\author{
STATISTICAL SURVEY OF THE INNOVATIVE \\ BACKGROUND OF UKRAINIAN \\ ENTERPRISES AGAINST THE RESSION
}

\author{
Горященко Юлія Григорівна \\ кандидат економічних наук, доцент, \\ Університет митної справи та фрінансів \\ ORCID: https://orcid.org/0000-0001-7020-1412 \\ Horiashchenko Yuliia \\ University of Customs and Finance
}

\begin{abstract}
У даній статті надано визначення інноваційного фрону підприємств й охарактеризовані його відмінні риси та основні компоненти. Інноваційний фон пропонується розглядати як інноваційне оточення підприємства, яке виразно його виділяє як результат розвитку інноваційної екосистеми. Проведено аналіз підприємницького, інвестиційного, фрінансового, соціального й освітньо-наукового потенціалу в умовах уповільнення темпів економічного зростання та розбудови інноваційної екосистеми, зокрема, зайнятого населення у сорерах інноваційного спрямування (сорери освіти, інформації, телекомунікації, професійної, наукової і технічної діяльності), рівня показника ВРП та ВРП на душу населення, кількості абонентів Інтернету, сальдо зовнішньої торгівлі товарами й послугами, рівня прибутковості великих, середніх і малих підприємств.
\end{abstract}

Ключові слова: інноваційний фон, інновації, підприємництво, рецесія, інноваційний розвиток, інноваційна екосистема, інноваційний простір.

В данной статье дано определение инновационного фона предприятий и охарактеризованы его отличительные черты и основные компоненты. Инновационный фрон предлагается понимать как инновационное окружение предприятия, которое выразительно его выделяет как результат развития инновационной экосистемы. Проведен анализ предпринимательского, инвестиционного, финансового, социального и научно-образовательного потенциала в условиях замедления темпов экономического роста и развития инновационной экосистемы, в частности, занятого населения в сфрерах инновационного направления (сферы образования, информации, телекоммуникации, профессиональной, научной и технической деятельности), уровня показателя ВРП и ВРП на душу населения, количества абонентов Интернета, сальдо внешней торговли товарами и услугами, уровня прибыльности крупных, средних и малых предприятий.

Ключевые слова: инновационный фон, инновации, предпринимательство, рецессия, инновационное развитие, инновационная экосистема, инновационное пространство.

This article provides a definition of the innovative background of enterprises and describes its distinctive features and main components. According to the results of the study, it is established that the innovation background, as an economic category, is currently being formed. As a phenomenon, it does not appear at the same time and is the result of the functioning of the innovation ecosystem. The innovation background is proposed to be understood as the innovative environment of the enterprise, which expressively distinguishes it as a result of the development of the innovation ecosystem. The analysis of entrepreneurial, investment, financial, social, scientific and educational potential in the context of a slowdown in economic growth and the development of an innovation ecosystem, in particular, of the employed population in the areas of innovation (education, information, telecommunications, professional, scientific and technical activities), has been carried out, the level of the indicator of GRP and GRP per capita, the number of Internet subscribers, the balance of foreign trade in goods and services, the level of profitability of large, medium and small enterprises. It has been established that the entrepreneurial and scientific and educational potential of the majority of enterprises in the regions is approaching compliance with the principles of the post-industrial economy and is developing on the basis of transforming knowledge, science and informatization into a direct productive force. The article proves that the information background is formed in accordance with the conditions of territorial development, it is characterized by the permanent nature of a sensitive socio-economic sys- 
tem (organism). Organizationally, it covers individual, group, business, industry, regional, mega-, meta- and other environments. The key metric for it is the level of development of the innovation ecosystem.

Keywords: innovation background, innovation, entrepreneurship, recession, innovation development, innovation ecosystem, innovation space.

Постановка проблеми. Проблеми розбудови інноваційної екосистеми та інноваційного простору становлять значний науковий та практичний інтерес. Тоді як дослідження інноваційного фону підприємництва в Україні майже не проводяться. Окрім того, у сучасній вітчизняній літературі навіть не склалося сталого поняття «інноваційний фрон».

Дослідження 3 визначення інноваційного фрону підприємництва на часі: по-перше, сьогодні інноваційний простір будь-якої просторової організації розвивається не лише виходячи із потреб комерційних ринків, а й за участю і пильною увагою держави, що говорить про його пріоритетність. По-друге, у сучасних умовах інноваційний простір володіє безмежними можливостями із розширення та наповнення його новим змістом, що прямо відображається на інноваційному фроні. По-третє, переважна більшість дослідників 3 питань (національного) інноваційного простору та інноваційної екосистеми сьогодні небезпідставно відводять їм головну роль у забезпеченні стійкого інноваційного розвитку підприємництва.

Аналіз останніх досліджень і публікацій. Проблеми інноваційного простору досліджені вченими О.А. Довгаль, Г.В. Довгаль, О.Б. Воєйковою, В.І Лячіним, В.О. Сизоненко, О.В Гуменною, О.Л. Богашко та ін.; питання розбудови інноваційної екосистеми - такими вченими, як Ч. Весснер, Р. Аднер, М. Рассел, К. Девлін, К. Фрімен, Ф. Даманпур, С. Меткалф, Ч. Едквіст, М. Гертлер, А. Кезін, Л.І. Федулова, Я. Піка, А. Янішевскі, Н.3. Солодилова, Ю.В. Малаховський, І.Ю. Підоричева та ін. [1-9].

Отож, понятійні новоутворення «інноваційний потенціал» та «інноваційна екосистема» наразі активно вивчаються вітчизняними фрахівцями і ученими, тоді як категорія «інноваційний фрон» взагалі малодосліджена. На нашу думку, це обумовлено тим фрактом, що досі немає загальноприйнятого визначення поняття «інновації», яке й зараз використовується головним чином на інтуїтивному рівні. 3 цієї ж причини, серед визначальних у даному контексті понять - «інноваційний простір», «інноваційна екосистема» також не існує однозначного трактування.

Формулювання цілей статті. Метою статті $€$ аналіз підприємницького, інвестиційного, фрінансового, соціального й освітньо-наукового потенціалу в умовах уповільнення темпів економічного зростання, з одного боку, та розбудови інноваційної екосистеми, з іншого.

Виклад основного матеріалу дослідження. Інноваційний простір доцільно розглядати як складну соціально-економічну систему, що складається 3 певної множини взаємопов'язаних об'єктів і яка перебуває в постійному русі у часі, періодично змінює свою «природу» відповідно до змін, що відбуваються на рівні включених в неї об'єктів [2]; інноваційну екосистему - як стійкі зв'язки між підприємствами, людьми і їх рішеннями, які виникають на підставі спільного бачення бажаних перетворень [3].

Поняття інноваційного фрону (фон - фрр. fond, від лат. fundus «основа») розуміємо як інноваційне оточення підприємства, яке виразно його виділяє як результат розвитку інноваційної екосистеми.

На нашу думку, оцінка інноваційного оточення підприємства має включати аналіз підприємницького, інвестиційно-срінансового, соціального, наукового й освітнього потенціалу. Чинники, які справляють вплив на фрормування інноваційного фону, умовно можна поділити на економічні, соціальні та екологічні. До економічних також слід віднести інвестиційні, фрінансові, технологічні, науково-технічні, інорормаційні; до соціальних - демограсрічні й культурні.

Важливість вивчення інноваційного фону зумовлена його природою: в умовах мега трендів світового розвитку окрім створення стратегій та оцінки потенціалу соціальноекономічних систем дуже важливою $є$ характеристика фрону, що є сьогодні: сприятливий інвестиційний клімат, готовність і здатність вести бізнес чи бути підприємцем, стратегічна зорієнтованість бізнес-еліти, громадськості і влади, рівень життя населення, оцінка соціально-економічного становища і т.ін.

Для дослідження економічних показників обрано підприємства м. Києва та усіх регіонів (за винятком тимчасово окупованої території Автономної Республіки Крим і м. Севастополя і частини окупованих Донецької та Луганської областей).

Готовність і здатність вести бізнес чи бути підприємцем $є$ важливим чинником формування інноваційного фрону, їі продемонстровано на рис. 1. 
Таблиця 1

Відмінні риси інноваційного фону

\begin{tabular}{|c|c|}
\hline $\begin{array}{l}\text { Інноваційний простір, } \\
\text { інноваційна екосистема }\end{array}$ & Інноваційний фрон \\
\hline $\begin{array}{l}\text { Теоретичний рівень - сфрормовані } \\
\text { нещодавно. } \\
\text { Практичний рівень - виникають у процесі } \\
\text { інноваційної діяльності }\end{array}$ & $\begin{array}{l}\text { Теоретичний рівень - наразі фрормується. } \\
\text { Практичний рівень - не з'являється водночас } \\
\text { (окрім інноваційних, на нього постійно } \\
\text { впливають історичні, економічні, соціальні } \\
\text { та інші чинники); у тому числі, є результатом } \\
\text { функціонування інноваційної екосистеми }\end{array}$ \\
\hline $\begin{array}{l}\text { Основними елементами визначено бізнес, } \\
\text { інфрраструктуру підтримки підприємництва, } \\
\text { інвестиційну та наукову сфреру }\end{array}$ & $\begin{array}{l}\text { Не має основних і другорядних суб'єктів / } \\
\text { акторів / елементів }\end{array}$ \\
\hline Виникають на стику інсрормації та інновацій & $\begin{array}{l}\text { Представляє собою інноваційне оточення } \\
\text { підприємств }\end{array}$ \\
\hline $\begin{array}{l}\text { Розбудовуються під впливом } \\
\text { глобалізаційних викликів }\end{array}$ & $\begin{array}{l}\text { Формується відповідно до умов } \\
\text { територіального розвитку }\end{array}$ \\
\hline Підтримується бізнес-моделями & $\begin{array}{l}\text { Має характер чутливої соціально-економічної } \\
\text { системи (організму) }\end{array}$ \\
\hline $\begin{array}{l}\text { Включає підприємців, університети, стартапи, } \\
\text { корпорації, інвестиційні та венчурні фронди, } \\
\text { уряд тощо }\end{array}$ & $\begin{array}{l}\text { Організаційно складається з індивідуального, } \\
\text { групового, підприємницького, галузевого, } \\
\text { регіонального, мега-, мета- та ін. середовища }\end{array}$ \\
\hline $\begin{array}{l}\text { Ключові метрики - ряд показників соціально- } \\
\text { економічної ефрективності }\end{array}$ & $\begin{array}{l}\text { Ключові метрики - рівень розвитку } \\
\text { інноваційної екосистеми }\end{array}$ \\
\hline $\begin{array}{l}\text { Життєвий цикл включає елементи } \\
\text { життєвого циклу галузі: start-up, консолідація, } \\
\text { зрілість тощо. }\end{array}$ & Перманентний характер \\
\hline $\begin{array}{l}\text { Основні ресурси розвитку: інтелектуальні, } \\
\text { інорормаційні, фрінансово-інвестиційні }\end{array}$ & $\begin{array}{l}\text { Результує і агрегує інноваційний розвиток } \\
\text { у вираженні інноваційного потенціалу } \\
\text { підприємств }\end{array}$ \\
\hline
\end{tabular}

Природно, що найбільша кількість малих підприємств спостерігалась у м. Києві 97710 од., найменша - у Луганській - 3524 од. та Чернівецькій області - 4028 од.

Лідером за кількістю середніх підприємств у 2019 р. було м. Київ (3989 од.), аутсайдером - Чернівецька (207 од.) та Луганська області (202 од.).

Безперечним лідером за кількістю великих підприємств у 2019 р. було найбільше українське місто Київ (165 од.), натомість у найменш чисельній серед усіх регіонів - Чернівецькій області - не було жодного підприємства 3 середньою кількістю працівників - понад 250 осіб та балансовою вартістю активів понад 20 мільйонів євро або ж чистим доходом від реалізації продукції (товарів, робіт, послуг) - понад 40 мільйонів євро (рис. 3).

Як видно з рис. 4, найвищий рівень прибутковості серед великих підприємств спостерігався в Житомирській та Рівненській областях, 3-поміж середніх підприємств - у м. Києві, серед малих - у Кіровоградській області.

Основні результати зовнішньоекономічної діяльності вітчизняних підприємств наведено на рис. 5-6.
В умовах надлишку товарів і послуг, від'ємне сальдо зовнішньої торгівлі товарами (різниця між вартістю експорту та імпорту) і відповідно низькі коесріцієнти покриття експортом імпорту у деяких регіонах, свідчить про складні економічні відносини між резидентами і нерезидентами, слабкість зв'язків зі світовим ринком позикових капіталів та низьку ефективність зовнішньоекономічної діяльності підприємств в цілому.

Дані рис. 5 засвідчують, що навіть в умовах відкритості економіки, прикордонні регіони демонструють від'ємне сальдо: Волинська область (межує з Білорусією і Польщею), Львівська (з Польщею), Одеська (з Румунією); напроти - додатне сальдо показують здебільшого старопромислові регіони, розташовані в центрі або на сході країни - Дніпропетровська, Полтавська, Донецька області. Найбільше від'ємне сальдо зовнішньої торгівлі товарами у 2019 р. спостерігалося в м. Київ (-10525752,1 тис. дол. США). Лідером за результуючим додатним показником сальдо $€$ Дніпропетровська область (2958029 тис. дол. США). У структурі експорту товарами цієї області переважали недорогоцінні метали і мінеральні продукти. 


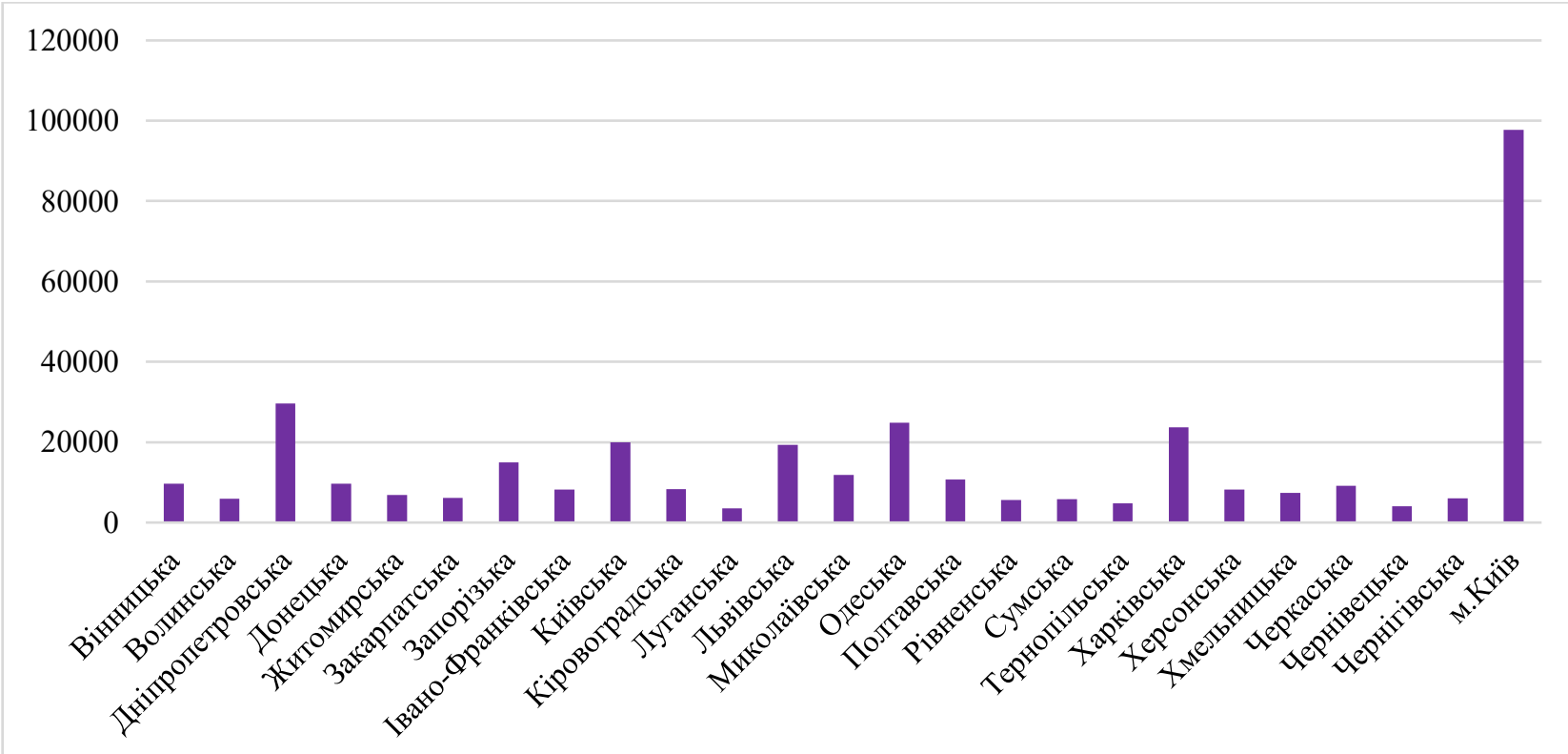

Рис. 1. Кількість малих підприємств, В т.ч. мікропідприємств за регіонами України, 2019 р., одиниць Джерело: побудовано за даними [10]

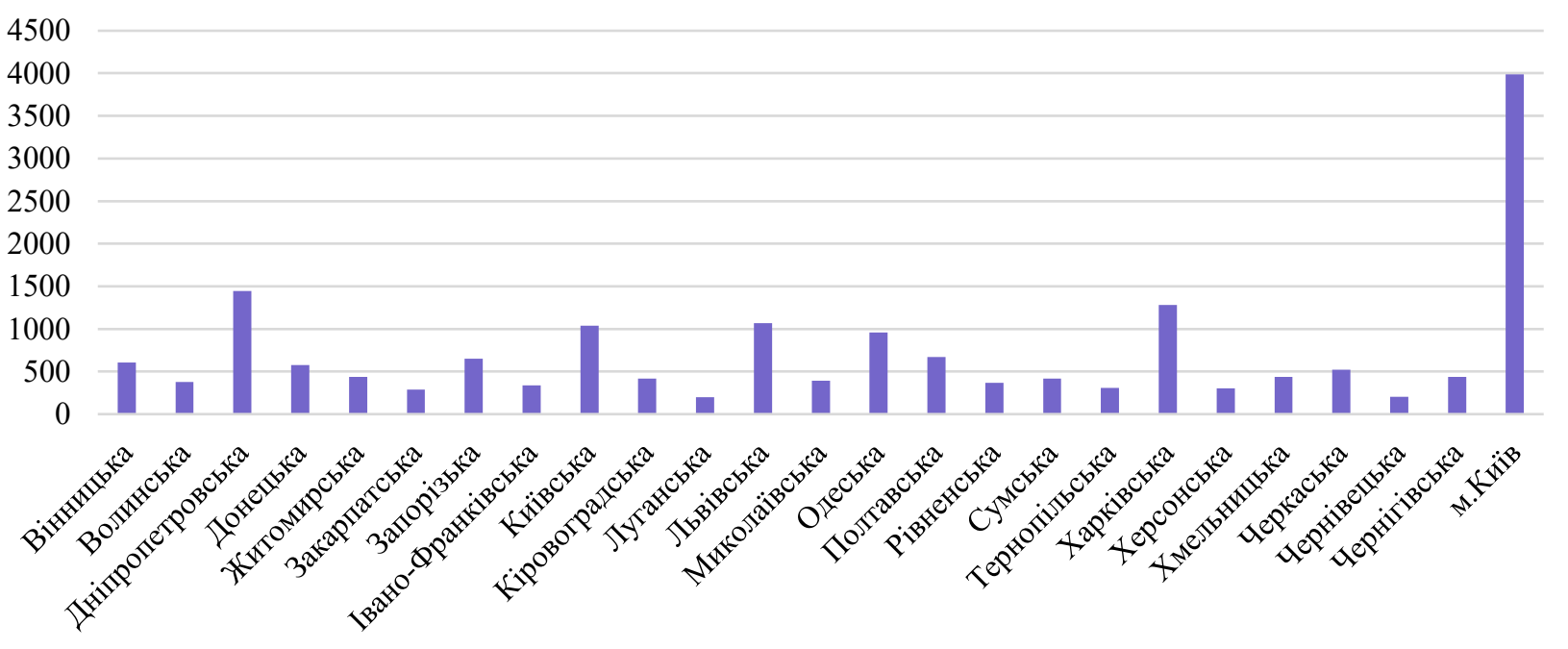

Рис. 2. Кількість середніх підприємств за регіонами України, 2019 р., одиниць Джерело: побудовано за даними [10]

Вимушені погодитись 3 думкою багатьох учених і практиків, зокрема, Капіталіною Гуровою та Андрієм Непраном, які констатують існування в Україні «моделі імпортоорієнтованого та боргонакопичувального невиробничого споживання» [11, с. 33].

Ситуація у сфрері зовнішньої торгівлі послугами значно відрізняється від торгівлі товарами, зокрема, лідером за результуючим додатним показником сальдо є м. Київ (1510862 тис. дол. США), натомість най- більше від'ємне сальдо зовнішньої торгівлі послугами у 2019 р. спостерігалося в Полтавській області (-56820 тис. дол. США) (рис. 6).

У структурі експорту послуг м. Києва переважали послуги у сорері телекомунікації, комп'ютерні та інфрормаційні послуги.

Як видно з рис. 7, в усіх регіонах переважна більшість (або абсолютна більшість) підприємств фрінансує інноваційну діяльність за рахунок власних коштів. Деяку підтримку держави, іноземних та вітчизняних інвесторів 


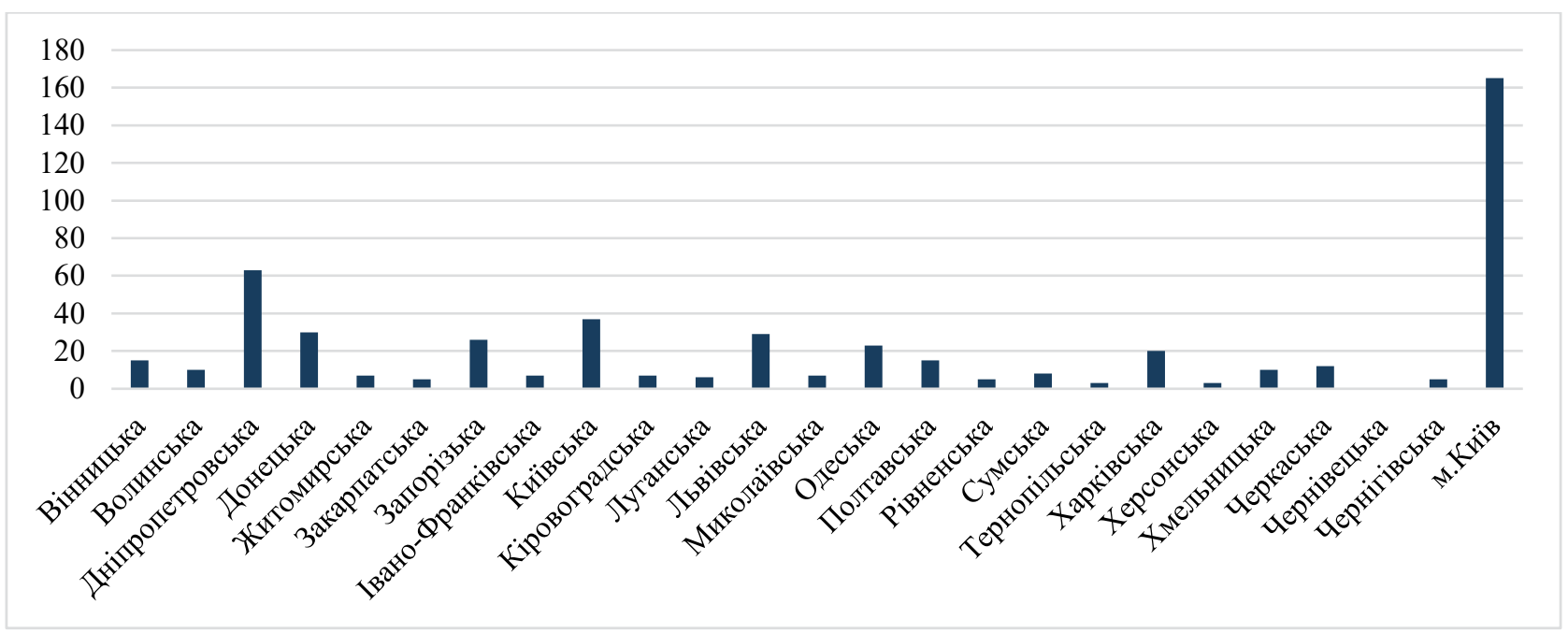

Рис. 3. Кількість великих підприємств за регіонами України, 2019 р., одиниць Джерело: побудовано за даними [10]

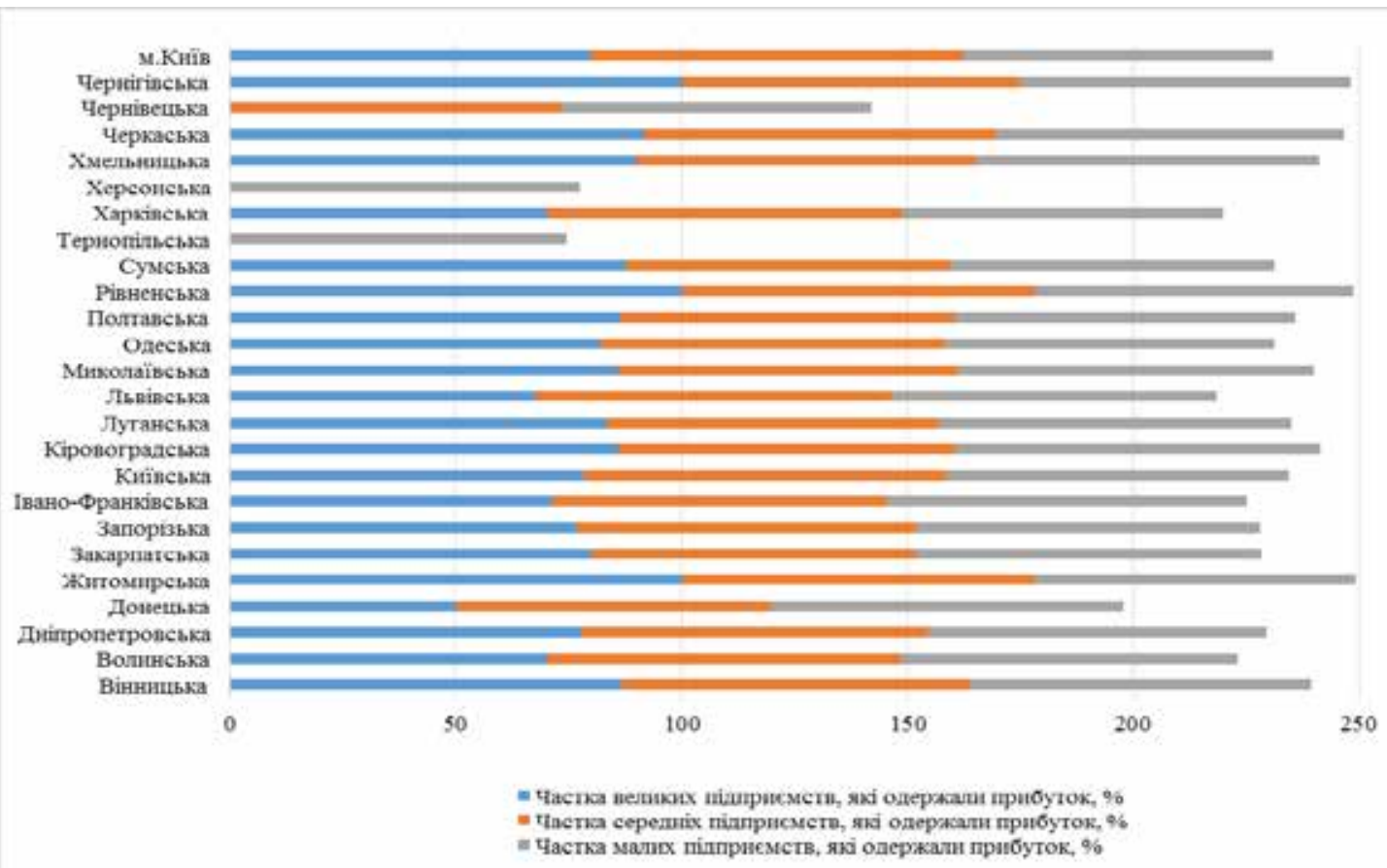

Рис. 4. Питома вага великих, середніх та малих підприємств, які одержали прибуток у 2019 році, за регіонами України, \%

Джерело: побудовано за даними [10]

отримують підприємства Дніпропетровської, Полтавської, Сумської, Тернопільської, Харківської областей та м. Києва.

Як видно з рис. 8, найбільша кількість абонентів Інтернету у 2019 р. спостерігалася у м. Києві (1843 тис.ос.), найменша-у Рівненській (63 тис.ос.) та Луганській (42 тис.ос.) областях.

Регіони 3 найвищими соціально-економічними показниками мають розвинений інноваційний простір та інноваційну екосистему; основні галузі економічного потенціалу фрормують структуру валового регіонального продукту, яка наближається до відповідності принципам постіндустріальної економіки i розбудовується на базі перетворення знань, науки та інфрорматизації (рис. 9).

Найвищий рівень показника ВРП у 2019 р. спостерігався у м. Києві (949531 млн. грн або 320886,2 грн на одного жителя міста), найнижчий показник - у Луганській та Чернівець- 


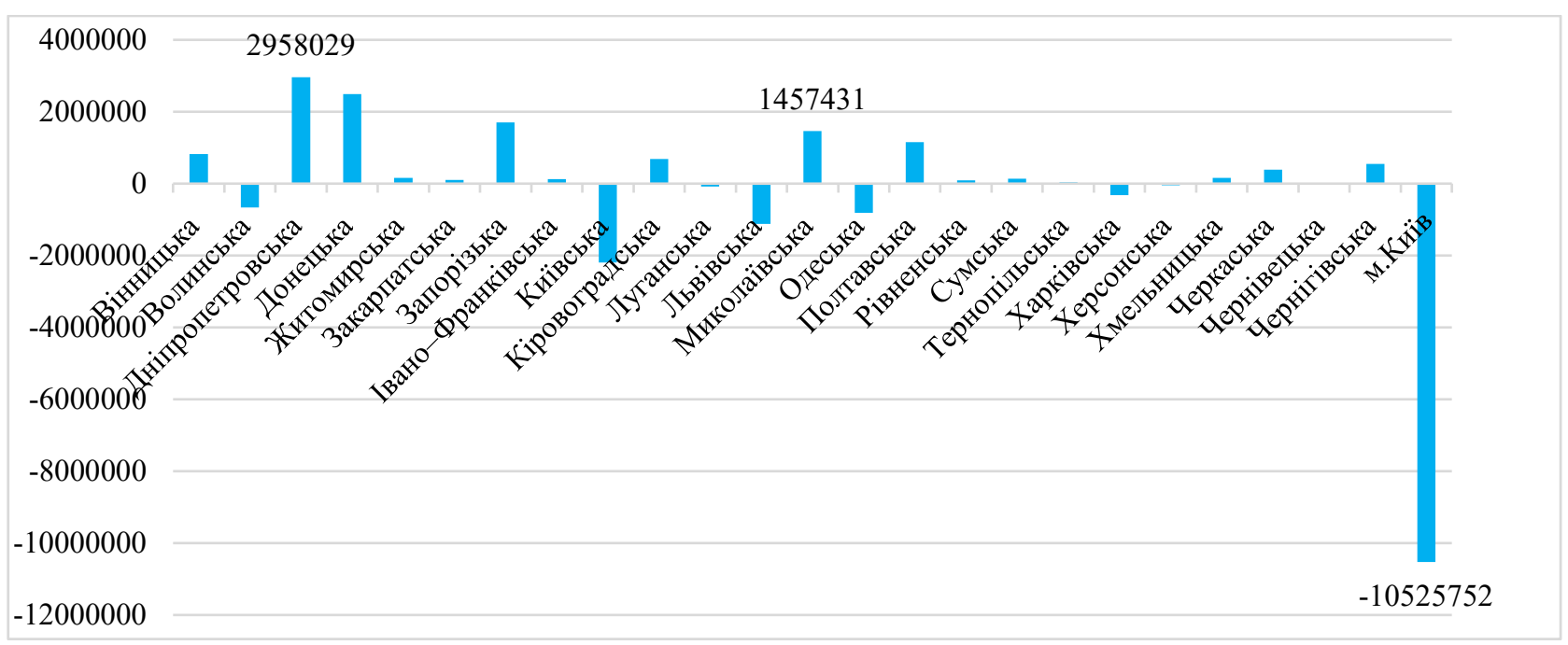

Рис. 5. Сальдо зовнішньої торгівлі товарами за регіонами України, 2019 р., тис. дол. США Джерело: побудовано за даними [10]

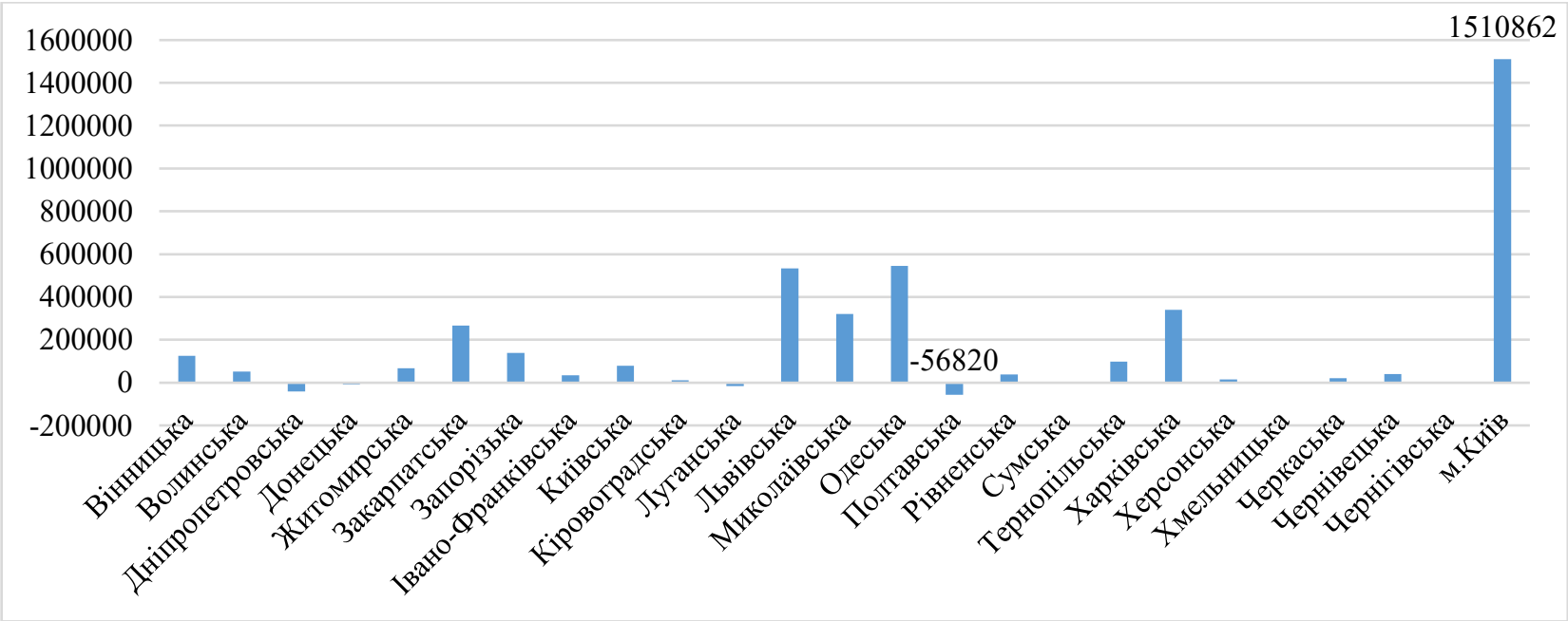

Рис. 6. Сальдо зовнішньої торгівлі послугами за регіонами України, 2019 р., тис. дол. США Джерело: побудовано за даними [10]

кій областях (відповідно 40300 млн. грн та 41661 млн. грн).

Найбільша кількість зайнятого населення у сорерах інноваційного спрямування у 2019 р. спостерігалася у м. Київ, найменша - у Луганській та Кіровоградській областях. У співвідношенні зайнятого населення в означених сорерах до середньої чисельності наявного населення у регіонах, отримуємо такі показники: у м. Києві кожна десята особа зайнята у ссрері освіти або інсрормації або телекомунікації або просресійної, наукової і технічної діяльності; в Київській та Харківській областях - кожна сімнадцята особа, у Дніпропетровській, Одеській, Тернопільській та Львівській областях - кожна двадцята особа (що відповідає середньому значенню по Україні).
Висновки. Методом конкретних та абстрактних порівняльних характеристик дійшли висновків, що найвищий підприємницький потенціал має м. Київ, де спостерігалась найбільша кількість зайнятого населення у сфрерах інноваційного спрямування (кожна десята особа зайнята у сорері освіти (або інорормації, телекомунікації, профресійної, наукової і технічної діяльності), найвищий рівень показника ВРП та ВРП на душу населення, найбільша кількість абонентів Інтернету, найвищий результуючий додатний показник сальдо зовнішньої торгівлі послугами, найвищий рівень прибутковості 3-поміж середніх підприємств серед усіх регіонів України.

Встановлено, що результує і агрегує інноваційний розвиток у вираженні інноваційного 


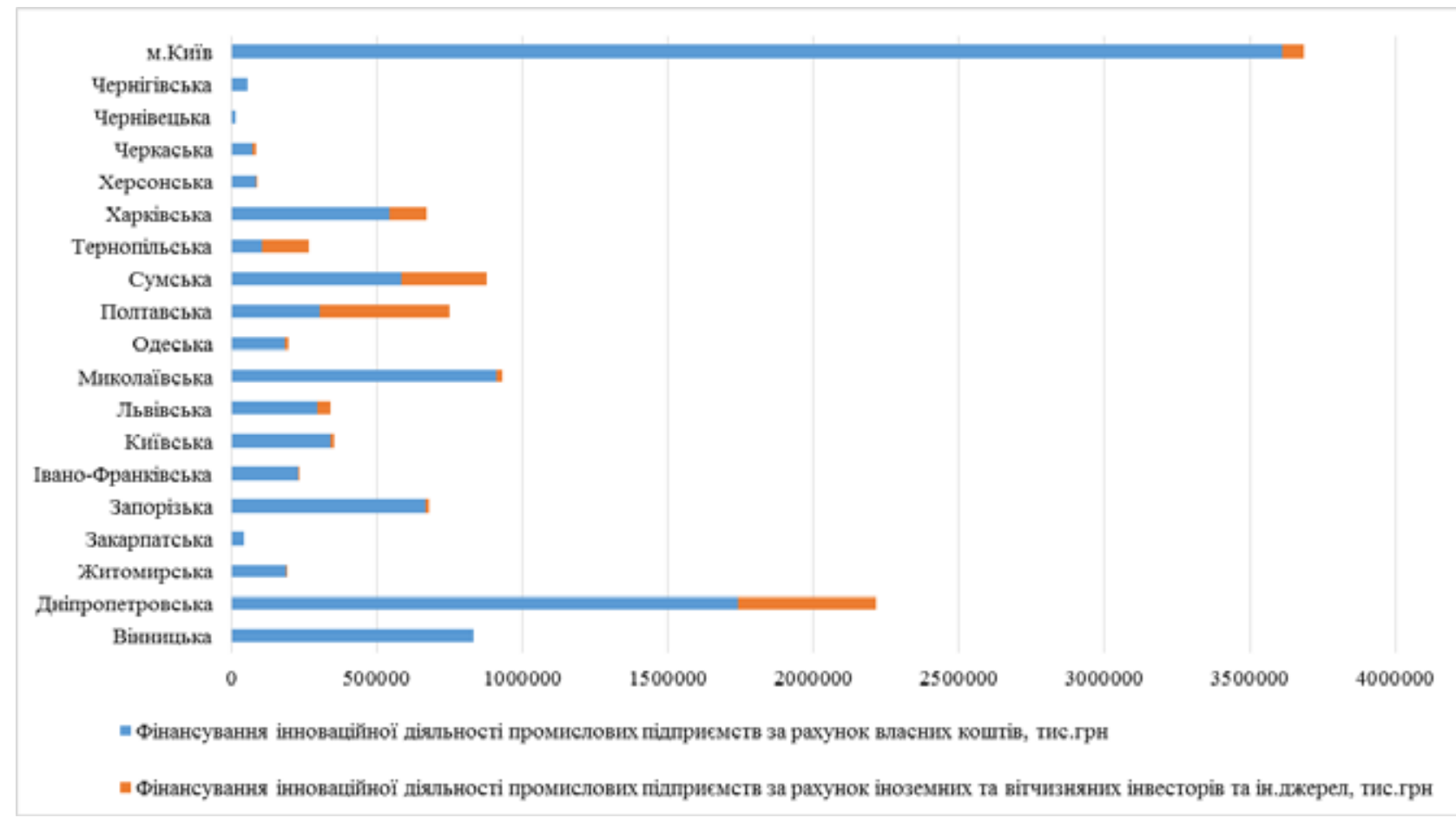

Рис. 7. Обсяг витрат на інновації у 2019 р., тис. грн

* відсутні дані Рівненської, Хмельницької, Волинської, Луганської та Донецької областей; побудовано за даними [10]

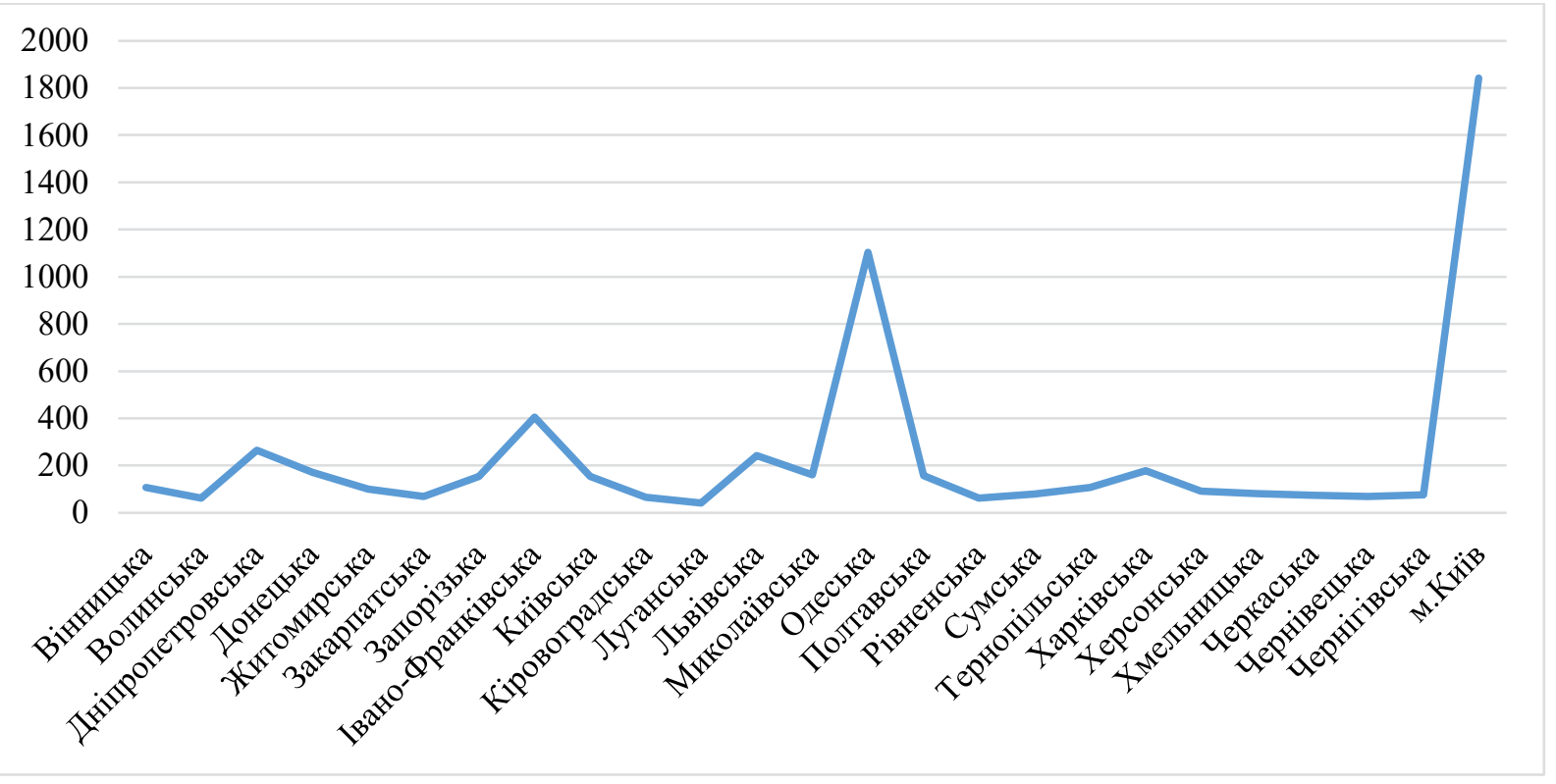

Рис. 8. Кількість абонентів Інтернету у 2019 р. за регіонами, тис. осіб [10]

потенціалу підприємств інноваційний фрон, який запропоновано розглядати як інноваційне оточення підприємства, що виразно його виділяє як результат розвитку інноваційної екосистеми. За результатами дослідження встановлено, що інноваційний фрон, як економічна категорія, наразі тільки формується. Як явище, він не з'являється водночас і є результатом функцціонування інноваційної екосис- теми. Інформаційний фон формується відповідно до умов територіального розвитку, йому притаманний перманентний характер чутливої соціально-економічної системи (організму). Організаційно він охоплює індивідуальне, групове, підприємницьке, галузевого, регіональне, мега-, мета- та інші середовища. Ключовою його метрикою $є$ рівень розвитку інноваційної екосистеми. 


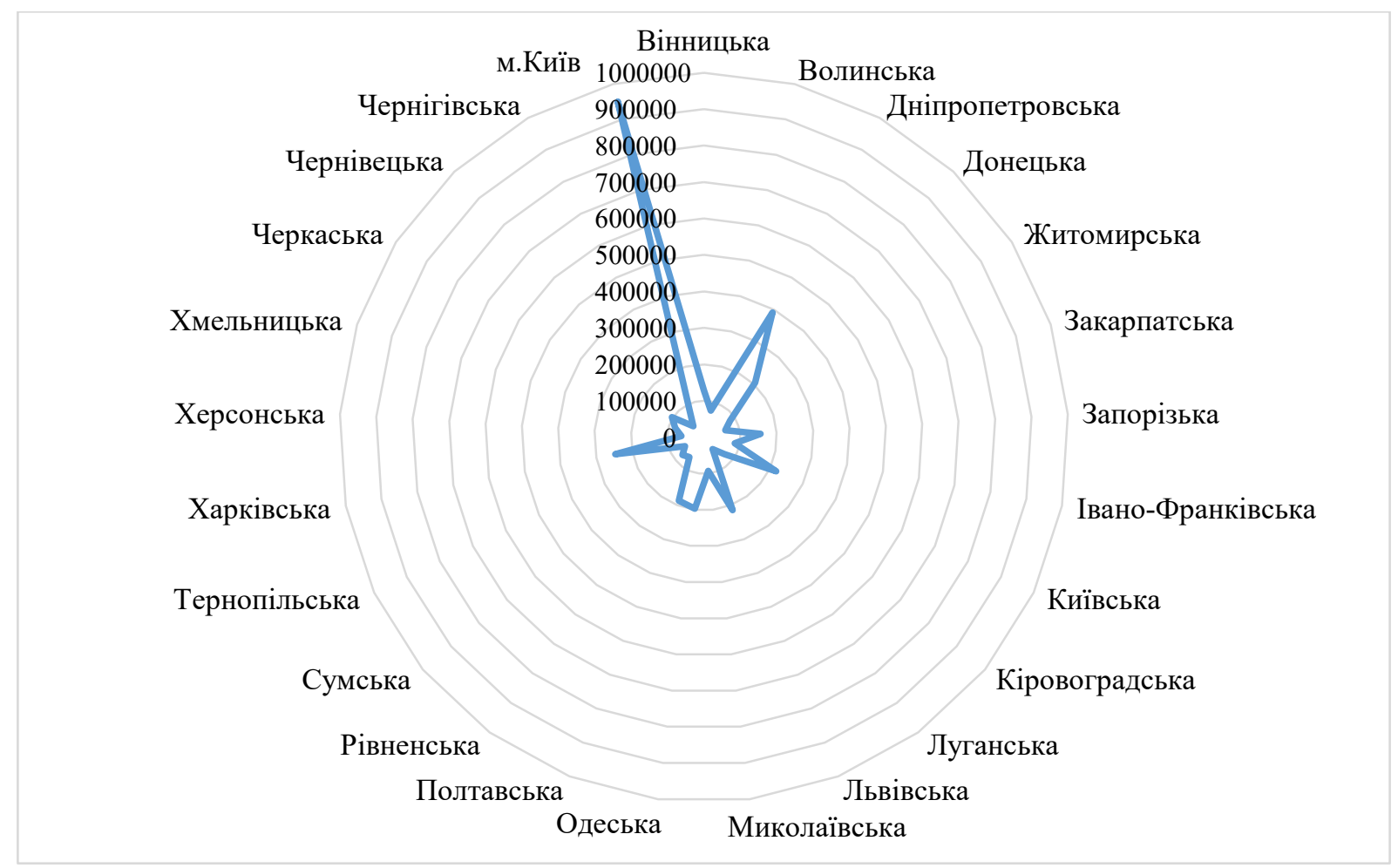

Рис. 9. ВРП у 2019 р. за регіонами, млн. грн

Джерело: побудовано за даними [10]

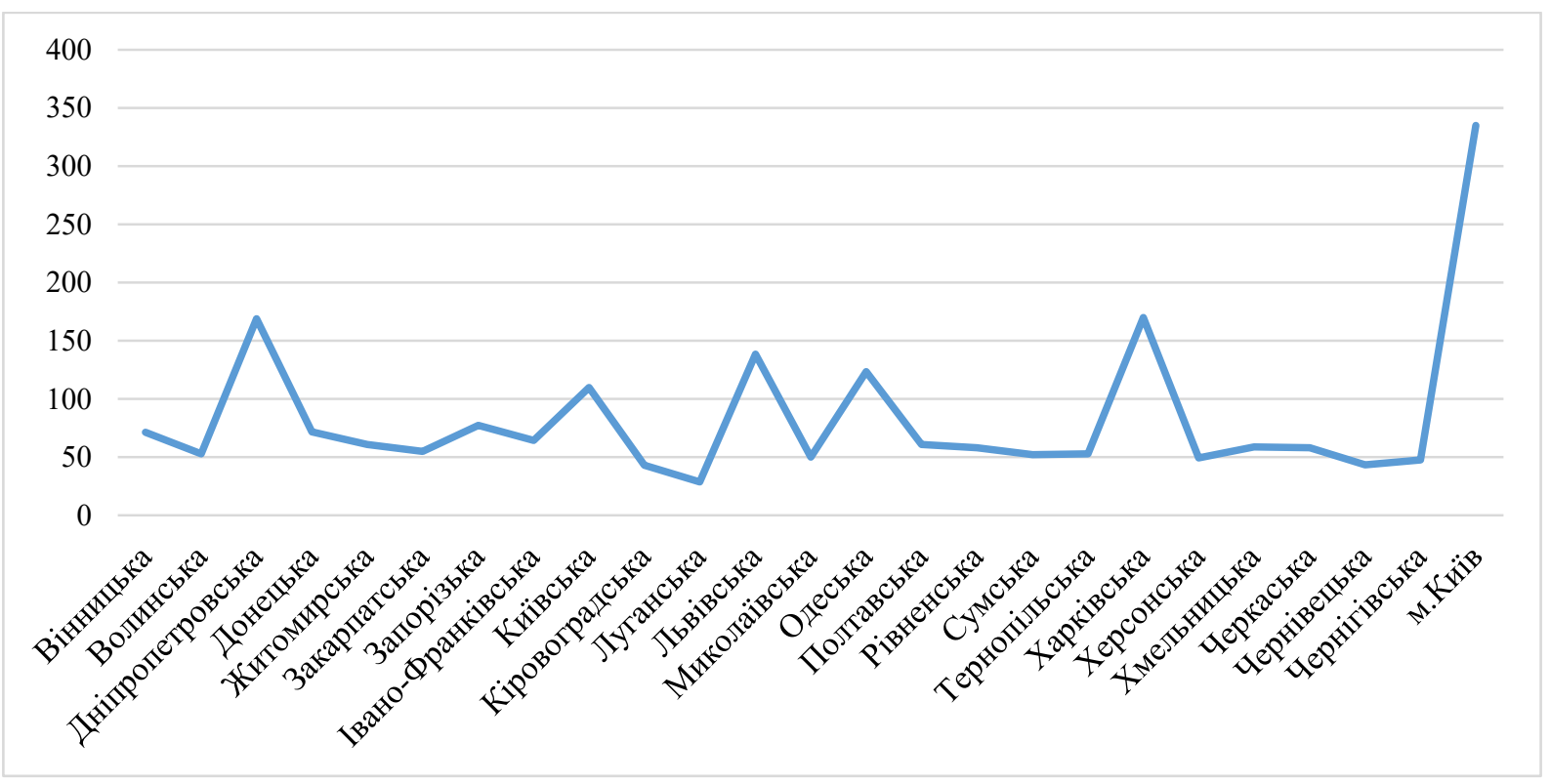

Рис. 10. Зайняте населення у сфері освіти, інформації, телекомунікації, професійній, науковій та технічній діяльності за регіонами, тис. ос.

Джерело: побудовано за даними [10]

СПИСОК ВИКОРИСТАНИХ ДЖЕРЕЛ:

1.Довгаль О.А., Довгаль Г.В. Глобальний інноваційний простір: передумови, специфріка й інструменти формування. Проблеми економіки. 2017. № 1. С. 15-20.

2.Воейкова О.Б., Лячин В.И. Категориальное определение инновационного пространства. Вестник СИбГАУ. 2015. Т. 16. № 4. С. 1014-1021. 
3. Russell M. G. et al. Transforming Innovation Ecosystems through Shared Vision and Network Orchestration I Triple Helix IX International Conference. Stanford, 2011. Pp. 1-21.

4.Підоричева І.Ю. Інноваційна екосистема в сучасних економічних дослідженнях. Економіка промисловості. 2020. № 2(90). С. 54-92.

5.Богашко О.Л. Розгляд сутності інновацій в умовах становлення перших теоретичних уявлень про них. Причорноморські економічні студії. 2018. Вип. 28(1). С. 5-9.

6. Гуменна О.В., Ганущак-Єфріменко Л.М. Формування споживчої цінності знань в інноваційній екосистемі. Актуальні проблеми економіки. 2014. № 2(152). С. 8-13.

7.Gopalakrishnan S., Damanpour F. Review of innovation research in economics, sociology and technology management. Omega. 1997. Volume 25. Issue 1. February. P. 15-28.

8.Кезин А.С. Генезис понятия инновации в профессиональном образовании: обретение сущности. URL: https://cyberleninka.ru/article/n/genezis-ponyatiya-innovatsii-v-professionalnom-obrazovanii-obretenie-suschnosti (дата звернення: 14.04.2021).

9.Горященко Ю.Г. Аналіз інформаційного фону регіонів України. Управління розвитком. 2010. № 17(93). С. 86-88.

10.Державна служба статистики України. URL: http://ukrstat.gov.ua/ (дата звернення: 20.04.2021).

11. Гурова К., Непран А. Зовнішньоторговельна діяльність у структурі доходів держави. Зовнішня торгівля: економіка, фрінанси, право. 2017. № 2. С. 31-49.

\section{REFERENCES:}

1.Dovhal O.A., Dovhal H.V. (2017) Hlobalnyi innovatsiinyi prostir: peredumovy, spetsyfika y instrumenty formuvannia [Global innovation space: preconditions, specifics and tools of formation]. Problemy ekonomiky, no. 1, pp. $15-20$.

2. Voejkova O.B., Lyachin V.I. (2015) Kategorial'noe opredelenie innovaczionnogo prostranstva [Categorical definition of the innovation space]. Vestnik SibGAU, no. 16(4), pp. 1014-1021.

3. Russell M.G. et al. (2011) Transforming Innovation Ecosystems through Shared Vision and Network Orchestration. Triple Helix IX International Conference. Stanford, pp. 1-21.

4.Pidorycheva I.lu. (2020) Innovatsiina ekosystema v suchasnykh ekonomichnykh doslidzhenniakh [Innovative ecosystem in modern economic research]. Ekonomika promyslovosti, no. 2(90), pp. 54-92.

5.Bohashko O.L. (2018) Rozghliad sutnosti innovatsii v umovakh stanovlennia pershykh teoretychnykh uiavlen pro nykh [Consideration of the essence of innovations in the formation of the first theoretical ideas about them]. Prychornomorski ekonomichni studii, no. 28(1), pp. 5-9.

6. Humenna O.V., Hanushchak-Yefimenko L.M. (2014) Formuvannia spozhyvchoi tsinnosti znan v innovatsiinii ekosystemi [Formation of consumer value of knowledge in the innovation ecosystem]. Aktualni problemy ekonomiky, no. 2(152), pp. 8-13.

7. Gopalakrishnan S., Damanpour F. (1997) Review of innovation research in economics, sociology and technology management. Omega, no. 25(1), pp. 15-28.

8. Kezin A.S. Genezis ponyatiya innovaczii v professional'nom obrazovanii: obretenie sushhnosti [The genesis of the concept of innovation in vocational education: finding the essence]. Available at: https://cyberleninka.ru/article/n/ genezis-ponyatiya-innovatsii-v-professionalnom-obrazovanii-obretenie-suschnosti (accessed 14 April 2021).

9. Horiashchenko Yu.H. (2010) Analiz informatsiinoho fonu rehioniv Ukrainy [Analysis of the information background of the regions of Ukraine]. Upravlinnia rozvytkom, no. 17(93), pp. 86-88.

10. Derzhavna sluzhba statystyky Ukrainy [State Statistics Service of Ukraine]. Available at: http://ukrstat.gov.ua/ (accessed 20 April 2021).

11. Hurova K., Nepran A. (2017) Zovnishnotorhovelna diialnist u strukturi dokhodiv derzhavy [Foreign trade activity in the structure of state revenues]. Zovnishnia torhivlia: ekonomika, finansy, pravo, no. 2, pp. 31-49. 